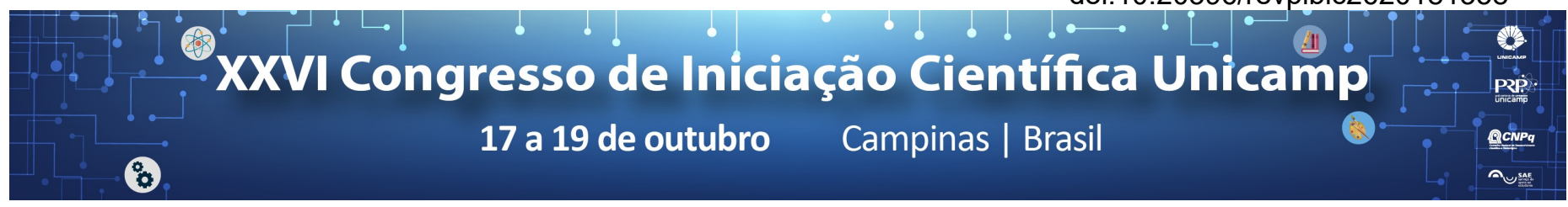

\title{
uso público da razão no Esclarecimento kantiano
}

\author{
Vinicius Pinto de Carvalho*, Monique Hulshof (orientadora)
}

\begin{abstract}
Resumo
Este projeto de pesquisa pretende analisar o conceito kantiano de uso público da razão desenvolvido por Kant no texto "Resposta à questão: O que é Esclarecimento?". Inicialmente, pretende-se investigar a problemática distinção entre uso público e uso privado da razão. O objetivo dessa primeira parte da pesquisa é abordar a questão: o que exatamente significa fazer um uso público da razão? Em seguida, tendo claras a definição desse conceito e a diferença entre uso público e uso privado da razão, pretendemos investigar o conceito de público (Publikum) empregado por Kant no texto em questão. Esse segundo momento da pesquisa visa compreender em que consiste esse Publikum do Esclarecimento, e, mais importante, quem faz parte dele.
\end{abstract}

\section{Palavras-chave: \\ Kant, Esclarecimento, Filosofia Moderna.}

\section{Introdução}

Tivemos como objetivo nesta pesquisa investigar o conceito kantiano de uso público da razão, com base texto Resposta à Questão: O Que é Esclarecimento?. Examinaremos esse texto num primeiro momento em busca de uma melhor compreensão da distinção entre uso privado e uso público da razão. Em um segundo momento, já tendo clara a definição do conceito de uso público da razão (e o que o diferencia do uso privado) pretendesse investigar o que é e quem faz parte do Publikum do Esclarecimento. Pretendemos abordar as seguintes questões: quem pode ser considerado, segundo Kant, um instruído? O que é o mundo letrado? Há alguma restrição (de gênero, social ou econômica) que se aplica àqueles que visam participar do Publikum do Esclarecimento? Em suma, procurarmos investigar o que é e quem faz parte do Publikum kantiano.

\section{Resultados e Discussão}

No texto já mencionado, Kant distingue entre o uso privado e o uso público da razão, e associa a essas duas noções os conceitos de menoridade e de maioridade, respectivamente. $\mathrm{Na}$ menoridade, temos os indivíduos que são responsáveis por determinado "posto ou encargo público"1. Nessa situação, espera-se que sigam a ordem hierárquica da Instituição a qual pertencem, não Ihes sendo permitido um questionamento ou revisão das ordens e determinações que recebem. Kant não vê problemas no uso privado da razão (pois é o que garante o correto funcionamento das Instituições), mas desde que os indivíduos tenham a liberdade de fazer uso público da razão. Neste caso, não se portam como funcionários públicos e como a parte de um "mecanismo", mas sim com "membros de uma inteira república"2, que têm a liberdade de discutir e questionar quaisquer assuntos enquanto instruídos (Gelehrter) perante um público letrado (Leserwelt). Em outras palavras, um soldado, por exemplo, faz uso privado da razão enquanto no ofício de soldado. Em serviço, ele não tem a permissão de questionar suas ordens, devendo simplesmente cumpri-las; contudo, enquanto mero cidadão, Kant argumenta que a ele deve ser dada a liberdade de questionar a legitimidade das ordens que recebe. É exatamente essa liberdade de fazer um uso público da razão que permite a passagem do já mencionado estado de menoridade ao estado de maioridade, como sintetizado na hoje conhecida passagem: "Esclarecimento é a saída do homem da menoridade pela qual é o próprio culpado"3. Há, porém, certas restrições a respeito de quem pode fazer uso público da razão. Ao longo da pesquisa analisamos outros textos de Kant (especialmente a Antropologia de um ponto de vista pragmático e a Metafísica dos Costumes) e concluímos que o uso público da razão é restrito ao gênero masculino. Isso se deve ao fato de que Kant repetidamente argumenta que o gênero feminino possui uma racionalidade deficiente, mais adequada a realização de atividades costumeiras e domésticas do que à argumentação pública ${ }^{4}$. Concluímos também que a concepção kantiana de cidadania impede que homens não proprietários façam uso público da razão em contextos legislativos.

\section{Conclusões}

Concluímos que Kant entende por "Esclarecimento" um certo processo no qual os cidadãos têm a liberdade de discutir e criticar publicamente as condutas e diretrizes das próprias Instituições do Estado. E é essa atividade que constitui o uso público da razão, em oposição ao uso privado, que diz respeito aos indivíduos enquanto funcionários ou membros dessas Instituições. Concluímos também que Kant exclui a possiblidade do gênero feminino de fazer uso público da razão, argumentando por uma certa racionalidade deficiente das mulheres, assim como excluí homens não proprietários de fazer uso público da razão em contextos legislativos, isso com base em sua definição de cidadania ativa.

\section{Agradecimentos}

Agradeço à Profa. Monique Hulshof pela orientação e aos colegas Pedro Ferreira e Lucas de Almeida. Agradeço também ao CNPq pelo apoio financeiro.

\footnotetext{
${ }^{1}$ Kant, I. Resposta à Questão: O que é Esclarecimento? In: MARÇAL, J (org.) Antologia de Textos Filosóficos. Curitiba: SEED - Pr., 2009, p. 409.

${ }^{2}$ idem.

3 ibid., 407.

${ }^{4}$ Kant, I. Antropologia de um Ponto de Vista Pragmático. São Paulo: Iluminuras, 2006, p. 306
} 